\title{
Green Supply Chain Practices: a comprehensive and theoretically multidimensional framework for categorization
}

\author{
Jairo José Assumpção ${ }^{\mathrm{a}}$ (D), Lucila Maria de Souza Campos: (D), Ana Beatriz Lopes de Sousa Jabbour ${ }^{\mathrm{b}}$ (D), \\ Charbel José Chiappetta Jabbour ${ }^{\mathrm{b}}$ (D), Diego Alfonso Vazquez-Brust ${ }^{\mathrm{a}, \mathrm{c}}$ (C) \\ aUniversidade Federal de Santa Catarina, Florianópolis, SC, Brasil \\ ${ }^{b}$ Montpellier Business School, France \\ 'Portsmouth University, Portsmouth, England \\ *Iucila.campos@ufsc.br
}

\begin{abstract}
Paper aims: The main objective of this work is to integrate a typology of green supply chain management practices with organizational theories.
\end{abstract}

Originality: We provide a comprehensive typology of GSCM practices based on empirical evidence and conceptual arguments.

Research method: Through a systematic review we identified 435 GSCM's practices that were organized into categories according to their theoretical conception, organizational context and characteristics.

Main findings: We identified three organizational context dimensions (innovation, performance and management) and proposed a conceptual model of theory-practice-context congruence, to guide the selection of theories for the design of research and analyses of GSCM practices.

Implications for theory and practice: Our main contribution is the alignment of each category of practices and organizational dimension with the selected theoretical lenses that can help future investigations to deepen the analysis of GSCM practices. Besides the theoretical contributions, we believe this contribution can also achieve practitioners.

Keywords

Environmental issues. Sustainability. Practice. GSCM.

How to cite this article: Assumpção, J. J., Campos, L. M. S., Jabbour, A. B. L. S., Jabbour, C. J. C., \& Vazquez-Brust, D. A. (2019). Green Supply Chain Practices: a comprehensive and theoretically multidimensional framework for categorization. Production, 29, e20190047. https://doi.org/10.1590/0103-6513.20190047.

Received: May 14, 2019; Accepted: Aug. 12, 2019.

\section{Introduction}

Despite more than 30 years of research and discussions on the subject of Green Supply Chain Management (GSCM), limited progress has been made in terms of radically curbing the aggregated environmental impacts of supply chains (Hartmann \& Moeller, 2014). This suggests that there is a gap in our knowledge, either in terms what needs to be done or in terms of how and why this should be done. In terms of what, this study considers GSCM practices as management activities related to supply chain integration and reverse logistics environmental oriented (Zhu \& Sarkis, 2007). Several publications on GSCM have proposed various types of green practices and initiatives (Rao \& Holt, 2005) from product design, material sourcing and selection, manufacturing processes, delivery of the final product to the consumers as well as end-of-life management of the product after its useful life (Srivastava, 2007). In terms of how, many conceptual frameworks have been presented by authors such as Sauer \& Seuring (2018), Centobelli et al. (2017), Holt \& Ghobadian (2009) and Hu \& Hsu (2010). These authors have strived to structure a GSCM practice framework to help understand this field and thereby identify the main barriers and drivers related to such practices. However, there is still a gap between frameworks and practices, 
since frameworks tend to assume that their hypothesis are equally relevant to all types of GSCM practices are equally. For instance, Rauer \& Kaufmann (2015) found out that companies face two categories of important external barriers implementation of GSCM practices: the first one related with the supply chain structure and the second one related to the environmental standards. They also argue that firms require three categories of dynamic capabilities to implement GSCM practices: sensing capabilities, alignment capabilities, and resilience capabilities. However, is still unclear how firms can effectively coordinate and normalize responses to barriers through their supply chain structure and how firms can develop dynamic capabilities that have supply chain scope. Improved understanding necessitates theoretical development, since as observed by Touboulic \& Walker (2015) plural theory building and testing are the basis for the development of knowledge in a discipline. We argue that frameworks for supply chain implementation need to embed more understanding of differences between types of practices and such understanding requires a more granular alignment of theories and practices, since theories are not all equally suitable to the adoption and diffusion of GSCM practices (Sarkis et al., 2011). However, theory in GSCM remains underdeveloped and there is not diversity in the use of theory to address distinct types of practices

Many GSCM frameworks treat GSCM practices as a black box (Cherrafi et al., 2018) or at the best, differentiate between upstream-downstream or between intra-organizational practices, dyadic practices and multi-tier practices involving the focal firm, a supplier and a third party (Sauer \& Seuring, 2018). Such classifications are based on supply chain structure; they do not take into account the idiosyncrasy of different practices. This is perhaps the consequence of some confusion about what involves a GSCM practice and which are the essential activities in a supply chain (SC). For example, the practice of 'using green packaging' (Rostamzadeh et al., 2015) is different from reducing or returning packaging (Darnall et al., 2008). The first one is a business policy, and the second is not necessarily integrated with the Supply Chain. In addition, due to the complex nature of the subject, there is a deficiency in published studies regarding the lack of an individualized and detailed theoretical-practical approach applied to different GSCM practices from the standpoint of organizational theories. Symptomatic of this is a highly cited study carried out by Sarkis et al. (2011), the researchers performed an extensive analysis of theories that can be used to explain GSCM practices implementation. However, they did not analyze the suitability of the theories described to explain different types of practices. Likewise, papers published describing the implementation of GSCM practices and providing more detailed typologies do not use different theoretical approaches for different practices. See for instance, an important paper by the same authors presenting a measurement model for the management and implementation of GSCM practices (Zhu et al., 2008a). A more recent example is Centobelli et al. (2017) WH2 framework. This model differentiates between single firm and supply chain practices, providing a typology of 4 aims, 6 tools and 6 practices. The practical focus of this model, however, does not integrate theories that can help researchers develop the model further.

A review of revisions in the GSCM supports our points. There is a vast body of literature reviews in the GSCM, but none of these papers provide a review of practices as well as theoretical guidance to develop practice-specific research. In a study by Oliveira et al. (2018) presented only an overview of the GSCM, pointing out the sector where GSCM is most recurrent and the most cited journal (Journal of Cleaner Production) and, similarly, the use of a management theory is absent by Tseng et al. (2019). A significant review is the paper by Srivastava (2007) but has not advanced in terms of categories and theories.

Their systematic literature review uses meta-analysis to describe the field of GSCM research. The authors identify key journals, most cited authors (Joseph Sarkis, Qinghua Zhu, Kannan Govindan, Ana Beatriz L. de Sousa Jabbour and Charbel J. C. Jabbour), methodologies and themes. The authors identify research in GSCM practices as a key theme linking thought with action. Malviya \& Kant (2015) also describe key authors, methodologies and trends. Identifying research in practices as important and signaling gaps, but fail to suggest theoretical directions to explore such gaps.

Islam et al. (2017) is a literature review of GSCM practices, the authors analyze 91 papers, they identifies 58 practices, which are divided in 15 categories. The authors neither explain the criteria for categorization, nor they mention theory. Srivastava (2007) classifies GSCM literature according to problem context (importance of GSCM, green design and green operations) and methodology (empirical and modelling). The authors focus on seven practices (LCA, ECD, 3R, inventory management, PP\&S RL, waste management), again theoretical directions are not addressed. Maditati et al. (2018) propose a conceptual framework. This framework take into account only the environmental aspect, without considering theory in the conception of the framework. Indeed, only Touboulic \& Walker (2015) and Koberg \& Longoni (2019) explore theories in GSCM, and they mainly provide a descriptive analysis without looking at applications of theories to practices.

Therefore, the main goal of this work is to integrate a typology of green supply chain management practices with organizational theories. To this end, we first carried on a literature review of environmental practices to 
identify consistent grouping of practices, then we identified emerging organizational contexts and conceptually linked each type practices with one or more contexts and theoretical approaches. Our paper has three main contributions.

Maditati et al. (2018, p. 158) noted "[...] a sound theoretical framework is lacking in most of highly cited GSCM research, which should be taken into account in future research". To address that concern this is the first time that a typology of GSM practices maps relevant theories to advance knowledge in each category. As such, our model will contribute to shaping the agenda of future GSCM research, which - as noted by Touboulic \& Walker (2015) - is still theoretically lagging, by facilitating decision-making in terms of what theoretical lenses are more suitable to analyze why and how particular GSCM practices are implemented and what practice-specific challenges are better addressed by what theory. The paper is structured into six more sections. Section 2 describes the methodological procedures of the research. Section 3 presents our proposed typology of GSCM practices. Section 4 presents a review of the main theories used to explain the phenomenon of GSCM practices (Sarkis et al., 2011). Section 5 describes the relationships uncovered. Section 6 presents the conceptual model proposing a structure that considers the organizational context, the theories based on its characteristics and eleven constructs of GSCM practices. Finally, Section 7 provides discussion and conclusion.

\section{Methodological procedures}

This systematic search for this study covered the period from 1996 to 2018. The databases used were Science direct and Scopus. The two terms "GSCM" and "Green Supply Chain Management" were adopted as filters, and title, summary and keyword filters were also used. From the search result, a RIS file was generated and imported into the EndNote X7 software. After cleaning up duplicity and not related articles, there were 383 articles remaining, of which only 103 presented the term "practice" in the title, keywords and abstracts. After reading the articles, we obtained a list of 577 practices declared by these articles. Such practices were recorded and organized, eliminating duplicates and identifying similarities. The final file resulted in 435 different practices.

Subsequently, they were organized into categories according to their theoretical conception, organizational context and characteristics. Our departing point for the categorization was Zhu et al. (2008a) paper, which proposed five categories of GSCM practices: (i) internal environmental management (IEM); (ii) green purchasing (GP); (iii) cooperation with customers (CC); (iv) ecodesign (ECO); and, (v) investment recovery (IR). Zhu and colleagues identified 21 practices related to the proposed categories. For example, "commitment of GSCM from senior managers" and "Support for GSCM from mid-level managers" was categorized within the Internal Environmental management (IEM) perspective, and so on. Using these five categories as initial coding criteria, we evaluate and classify the 435 identified activities, which are specified in Table 1. For example, collects used packaging from customers for recycling was registered as an activity within the category of reverse logistics practices and found that 74 of them did not fit in any of the coding categories. We conducted a second round of evaluation looking for similarities and differences between these practices and as a result we identified six new categories: (i) environmental innovation (El); (ii) environmental performance (EP); (iii) green compliance (GC); (iv) green marketing (GM); (v) suppliers relationship (SR); and, (vi) reverse logistics (RL).

These categories emerged due to the increase of identified papers between 2008 and 2017 and their concern for themes that at the time were treated in a superficial way. For example, several authors such as Eltayeb et al. (2011) began to measure performance of GSCM, therefore a new category was inserted. Other issues also appeared repeatedly in papers related to GSCM practices, and gave rise to new categories, such as cooperation with suppliers (Sarkis et al., 2011; Singhal, 2013); green marketing (Holt \& Ghobadian, 2009; Tseng \& Chiu, 2013); and compliance (Govindan et al., 2014; Eltayeb et al., 2011; Holt \& Ghobadian, 2009).

\section{Typology of GSCM practices}

Table 1 presents the typology of GSCM's practices and a summary of practices representative of those included in each category. The first 5 categories ( 1 to 5) are those based on Zhu et al. (2008b).

\section{Organizational theories in GSCM}

Sarkis et al. (2011) identified nine organizational theories with potential to be applied to explain GSCM. However, they did not expand on its suitability within the scope of GSCM practices. We present a synthesis on such theories, possibilities for GSCM research and problems inherent in its application to GSCM. In addition, we show how many of the articles reviewed have used these theories. 
Table 1. The main GSCM's practices.

Cat. 1: Internal Environmental Management (IEM)

\section{Practices}

Environmental management systems - 1S0 14001 certification Green manufacturing

Green packaging

Green product use

Green/Clean production

Green stock practices

Total quality management with emphasis on the environment

Replacement of toxic inputs by environmentally correct inputs Use of fewer inputs to minimize environmental risks and impacts Internal recycling of inputs, materials and waste

Use of Ecolabels, taking into account environmental criteria

Cat. 2: Green Purchasing (GP)

\section{Practices}

Green Purchasing or Buying environmentally friendly materials

Notice to buyers on reduction of environmental impacts

Establish standards for raw materials that do not contain prohibited substances

\section{References}

Vachon \& Klassen (2006); Zhu \& Sarkis (2007)

Shang et al. (2010)

Shang et al. (2010)

Zhu et al. (2011); Tseng \& Chiu (2013)

Vachon \& Klassen (2006); Tseng \& Chiu (2013); Zhu \& Sarkis (2007); Sang et al. (2013)

Tseng \& Chiu (2013); Vachon \& Klassen (2008); Wan Mahmood (2013)

Cat. 3: Cooperation with customers (CC)

\begin{tabular}{cccc} 
& Cat. 3: Cooperation with customers (CC) & \\
\hline Practice & References \\
\hline
\end{tabular}

Customer focused ecodesign projects

Sang et al. (2013); Zhu et al. (2016)

Cooperation with customers for cleaner production or to change

product specifications

Cooperation with customers to use less energy during transportation of

Zhu et al. (2016)

the product

Cooperation with customers for the returned product

Cooperation with customers for reverse logistics relationship

Practices to provide consumers with information on environmentally

friendly products and on production methods

\section{References}

Rao \& Holt (2005)

Arimura et al. (2011)

Chien \& Shih (2007)

Tseng \& Chiu (2013); Zhu et al. (2008a, b); Sarkis (2009);

Wan Mahmood (2013)

Cat. 4: Ecodesign (ECD)

Practices References

Design products to reduce the consumption of raw materials and energy

Sang et al. (2013); Zhu et al. (2015)

Design products for reuse, recycling, recovery of materials and components

Design products to avoid or reduce the use of hazardous products in

the manufacturing process.

Design products for environmentally friendly objectives

Srivastava (2007); Hu \& Hsu (2010)

Green and Ecodesign Projects

Cat. 5: Investment Recovery (IR)

\section{Practices}

Sale of scrap, used materials and surplus stocks

Recovery of company equipment at end of life

Sale of unused raw materials

\begin{tabular}{lc}
\hline \multicolumn{1}{c}{ Cat. 6: Environmental innovation (El) } \\
\hline \multicolumn{1}{c}{ Practices } & References \\
\hline Innovations in R\&D to provide environmentally friendly and low-cost & Tseng Chiu (2013) \\
Increase the competitiveness of new green products, meeting the needs & Vachon (2007); Wan Mahmood (2013) \\
of environmentally conscious customers & Vachon \& Klassen (2008) \\
Investment in green equipment and technology & \\
Use of alternative energy sources & \\
Use of cleaner technological processes to save energy, water and waste & \\
Incentive programs for employees who contribute to environmental & \\
suggestions
\end{tabular}


Cat. 7: Environmental Performance (EP)

\begin{tabular}{lc}
\multicolumn{1}{c}{ Practices } & References \\
\hline $\begin{array}{l}\text { Assessment of environmental performance } \\
\text { Environmental Accounting }\end{array}$ & Zhu \& Sarkis (2004) \\
Susivastava (2007); Rao \& Holt (2005)
\end{tabular}

Sustainability reporting

Integrated Reporting

Indicators of technical, economic and environmental performance

Tseng \& Chiu (2013)

Monitoring of environmental compliance

Vachon \& Klassen (2008)

Internal Auditing of environmental performance

External Auditing of environmental peformance

Third Party Certification of Environmental practices

Vachon \& Klassen (2008)

Cat. 8: Green Compliance (GC)

\section{Practices}

Compliance with environmental laws in relation to international agreements and national guidelines

Environmental Management and Legal Compliance

Compliance with EU environmental legislation and guidelines for compliance with environmental legislation in the future

Compliance and environmental auditing programs, including environmental requirements of regulators and customers,

Compliance and Environmental auditing for internal supplier Management

\section{Cat. 9: Green Marketing (GM)}

Practices References

\section{Green Marketing Mix}

Green Image or Branding

Community campaigns related to the environment

Green Endomarketing. Internal environmental education and training aiming at ecological practices

Green-oriented organizational involvement
Hu \& Hsu (2010); Shang et al. (2010)

Zhu et al. (2011)

Carter et al. (2000)

Hu \& Hsu (2010); Zhu et al. (2016)

Zhu et al. (2016)

\begin{tabular}{ccc}
\hline & Cat. 10: Suppliers Relationship (SR) & \\
\hline Practices & References \\
\hline
\end{tabular}

Allocate funds to help suppliers in their environmental program Vachon \& Klassen (2006); Zhu et. al (2016)

Collaborate with suppliers to manage reverse flows of materials and packaging

Sharing responsibilities with suppliers encouraging them to adopt more

Thun \& Muller (2010) environmentally friendly behaviors

Providing project specification for vendors that include environmental requirements for items "puchased"

Inform suppliers about the benefits of producing and using cleaner technologies

Require Supplier Certification; Suppliers Certification 1S014001

Cooperating with suppliers to address consumer environmental issues at

the end of the product life cycle

Zhu et al. (2012)

Zhu et al. (2016)

Zhu \& Sarkis (2007); Zhu et al. (2012)

Singhal (2013)

Cat. 11: Reverse Logistics (RL)

\section{Practices}

Reverse logistic

Collection and recycling of end-of-life products and materials

Establishment of a transport system for the recycling of used and defective end-of-life products

Collect, manage and dispose of the product at the end of its life cycle

Return process of product packaging after use
References

Srivastava (2007); Darnall et al. (2008); Beamon (1998); Wan Mahmood (2013); Eltayeb et al. (2011); Ellram et al. (2008); Zhu et al. (2008a)

Zhu et al. (2011)

Srivastava (2007)

Wan Mahmood (2013) 


\subsection{Complexity theory}

Complexity theory emphasizes the growing complexity and interdependences of social and economic life, a result of the rapidly evolving technology, communication and transportation (Merry, 1995). The theory and related theories such as Systems theory are highly relevant to study GSCM practice. Its application requires that interactions between the supply chain and environmental, economic, regulatory, social and political context should be carefully mapped at the macro, meso and micro level (Bai \& Sarkis, 2010). Patterns of relations and critical variables should be identified through quantitative or qualitative modeling. The main problem is the operational difficulty of applying the theory.

\subsection{Information theories (asymmetric information or signaling theory)}

These theories (Akerlof, 1970) assume that there is often a considerable gap of information, regarding the quality of a product, between the seller and the buyer. Only after using the product, the buyer can fill this information gap and begins to evaluate the product in a different manner (Delmas \& Montiel, 2009). The greater the information asymmetry between companies and stakeholders (e.g. customers and suppliers) the more reassurances companies must provide to customers, usually bringing an external party to fill the information gap and certify their practices (Sarkis et al., 2011). The theory narrow focus limits its application to GSCM to auditing, reporting and certification practices involving multiple supply chain actors.

\subsection{Institutional Theory (1T)}

Institutional theory says that external pressures influence organizations to adopt similar patterns of behavior (isomorphism) (DiMaggio \& Powell, 1983) in order to gain legitimacy and conform to prevailing social norms. Coercive pressures mainly arising governments, normative pressures arising from industry standard and customers, and mimicking the behavior of successful peers are key mechanisms for isomorphism (Clemens \& Douglas, 2006). The problem with IT is that ignores or underestimates the role of agents and individual level factors, such as feelings and beliefs, but also organizational aspects such as capabilities, power struggles and politics.

\subsection{Resource Based View (RBV)}

RBV sees companies as a set of resources and competencies that allows them to compete and implement specific strategies (Hart, 1997). When resources are Valuable, Rare, Inimitable and Non-substitutable (Hart, 1997) they can help companies to distinguish themselves, maintaining competitive advantage over time. Hart (1997), in the natural resource based view of the firm (NRBV) argues that environmental Management in an organization is a strategic resource that can lead to superior and constant performance (Vachon \& Klassen, 2006; Hart, 1997), specially through practices developing dynamic capabilities such as the implementation of environmental technology innovations, continuous learning and stakeholder integration (Sarkis et al., 2011). The problem with RBV is its focus on competition and in companies building and defending their own resources, while GSCM is characterized by co-operation and strategic sharing of resources.

\subsection{Resource Dependence Theory (RDT)}

RDT suggests that firms depend on resources provided by other people or organizations in order to survive (Pfeffer \& Salancik, 1978). An organization highly dependent on a particular resource, will aim to leverage a vertical integration strategy or to developed interdependent relations with resources suppliers (Pfeffer \& Salancik, 1978). Vertical coordination becomes even more important when there are few, powerful, resource suppliers and there is uncertainty in the company's operating environment (Carter \& Rogers, 2008). Supply chain members are interdependent and should collaborate to pursue greater long-term performance gains rather than seeking short-term benefits (Shang et al., 2010). For instance, Product ecodesign, supply chain certification and material recovery require chain partnerships to achieve performance benefits. Application of RDT to GSCM research is hindered by relative paucity of empirics, compared to Stakeholders Theory (ST) or IT. 


\subsection{Social Network Theory (SNT)}

SNT (Wasserman \& Faust, 1994) considers organizational outcomes as a function of the social relationships between organizations or individuals. These relations are seen as channels for transfer and flow of material or non-material resources (Wasserman \& Faust, 1994). Under the lens of the SNT, GSCM studies might attempt to explain, through their centrality in a network, the relationships between buyer and supplier for improving performance. Using the notion of network density, it is observed that organizations with a greater number of sites, customers, suppliers and general public awareness are likely to be under more pressure to adopt GSCM practices and have less control over whether they should or should not adopt such practices (Sarkis et al., 2011).

\subsection{Transaction Cost Economics (TCE) theory}

TCE (Williamson, 1981), focuses on identifying whether it is cost-effective to carry-out an activity using the market exchanges. Using the market has transaction costs -for instance contract design, monitoring and control- that need to be added to the accounting costs of using a contractor. Markets, hierarchies (using firm resources) or hybrids (e.g. long-term relations with exclusive suppliers) are alternative forms of governance of the firm (Williamson, 1981). For instance, when companies outsource processes that have detrimental effects on the environment, they need to account for increased monitoring and control costs to mitigate responsibilities and damaged reputation. The problem with the use of TCE to analyze GSCM practices is that TCE focus on the costs of one-to-one transactions while SC introduces a broader perspective in which transactions are grouped and managed as chains between organizations rather than as individual transactions (Williamson, 1981).

\subsection{Stakeholders Theory (ST)}

ST (Freeman \& McVea, 2001) argues that firm's activities produce externalities impacting on stakeholders (any group or individual who can affect or is affected by the achievement of the organization's objectives). Stakeholders put pressure on companies to reduce perceived negative impacts and increase positive ones. Because corporate resources are limited, firms should prioritize the more salient stakeholders (Mitchell et al., 1997). Prioritizing takes into account attributes (power, legitimacy and urgency), purposes (what do they want), and methods (what do they do to succeed) (Frooman, 1999). Stakeholders theory has been applied to study the adoption of green purchasing practices (Sarkis et al., 2011), reverse logistics (Zhu et al., 2008b), life cycle analysis, SC greening, customer pressures for environmental performance improvements and regulatory requirements (Zhu \& Sarkis, 2007), but the theory shows limitations when the interests of salient stakeholders diverge.

\subsection{Ecological Modernization Theory (EMT)}

EMT argues that joint accomplishment of industrial development and environment protection can be achieved through preventive innovation, state planning and coordination and technological development. Jänicke (2008) and Murphy \& Gouldson (2000) including innovations in products, processes, technologies and management (Mol \& Spaargaren, 1993). Both the state (e.g. means of regulation) and market (companies and customers) must take on new roles in order to contribute to better protect the environment (Mol \& Spaargaren, 1993).

The state needs to be a more flexible, decentralized and preventive institution that creates networks with other social actors and applies a variety of approaches and tools beyond coercion (Weale, 1992). Market actors must create solutions that mitigate the impacts of industrial development (Weale, 1992). EMT is a macro-level theory that requires integration with meso-level theories to explain GSCM practices. It has been applied, for instance, in combination with RDT to analyze the development of corporate innovation and cooperative supply chain practices in response to green regulation (Sousa Jabbour et al., 2017).

\section{Emerging organizational dimensions and relationships}

Further interpretative review of our articles resulted in the identification of three organizational dimensions for the GSCM analysis. These dimensions aim at positioning the GSCM practices from the perspective of the organizational structure and, thus, to construct a logical reasoning for theories that try to explain the phenomenon. Each dimension describes the elements that are closely interrelated and fundamental to operationalize a SC, namely: business processes (creating value for stakeholders), chain components (management variables) and structure (network of members). 
The first dimension is that GSCM can be considered a relatively advanced technological innovation for organizations to improve their environmental performance (Carter \& Rogers, 2008). This is in the scope of business processes with the goal of generating value for stakeholders through new environmental technologies and dependent on management variables and a broad network of cooperation.

The second dimension is that the effect of GSCM practices on organizational performance suggests that they have achieved consistent results after their implementation. This occurs in the structure of SC through a network of cooperation between individuals, so that they can disseminate knowledge and experiences. Given these perspectives, the GSCM can be considered an organizational technological innovation that contributes significantly to its environmental performance (Zhu et al., 2008a; Sarkis \& Cordeiro, 2012). The third dimension is that companies can implement GSCM in a more complex way (for example through lean manufacturing) (Campos $\&$ Vazquez-Brust, 2016) or in a simpler way (for example, collaboration for ecodesign projects) (Zhu et al., 2011), thus directly linked to operations management. Therefore, the GSCM needs to be operationalized through a structure that improves the relationships among all the components of the chain, with the objective of directing value to all those that compose it. From these three findings and the analysis of practices in light of the revised theories, eleven categories were proposed.

For each construct, the main characteristics and activities of the GSCM practices identified in the literature review will be anticipated. From this description, it will be suggested an organizational dimension and the theories that, from the characteristics presented in Figure 1, will be more adequate to explain the construct.

\subsection{Internal Environmental Management (IEM)}

IEM is centered on the premise that environmental development is a strategic organizational imperative, and middle and senior level managers are responsible to implement environmentally friendly practices (Zhu et al., 2008a). This construct is full of GSCM practices, considering more operational and day-to-day activities of SC components; thus, it is included in the organizational context of operations management. A second set of IEM practices refers to practices aimed to support high and medium-commitment management. In this case, the commitment operates as a facilitator in the implementation of GSCM practices, but when there is no commitment, the absence becomes a barrier. The stakeholder theory can help explain the power of different stakeholders to implement GC practices and how high and medium-commitment management respond to pressures, making it difficult or easier to implement such practices.

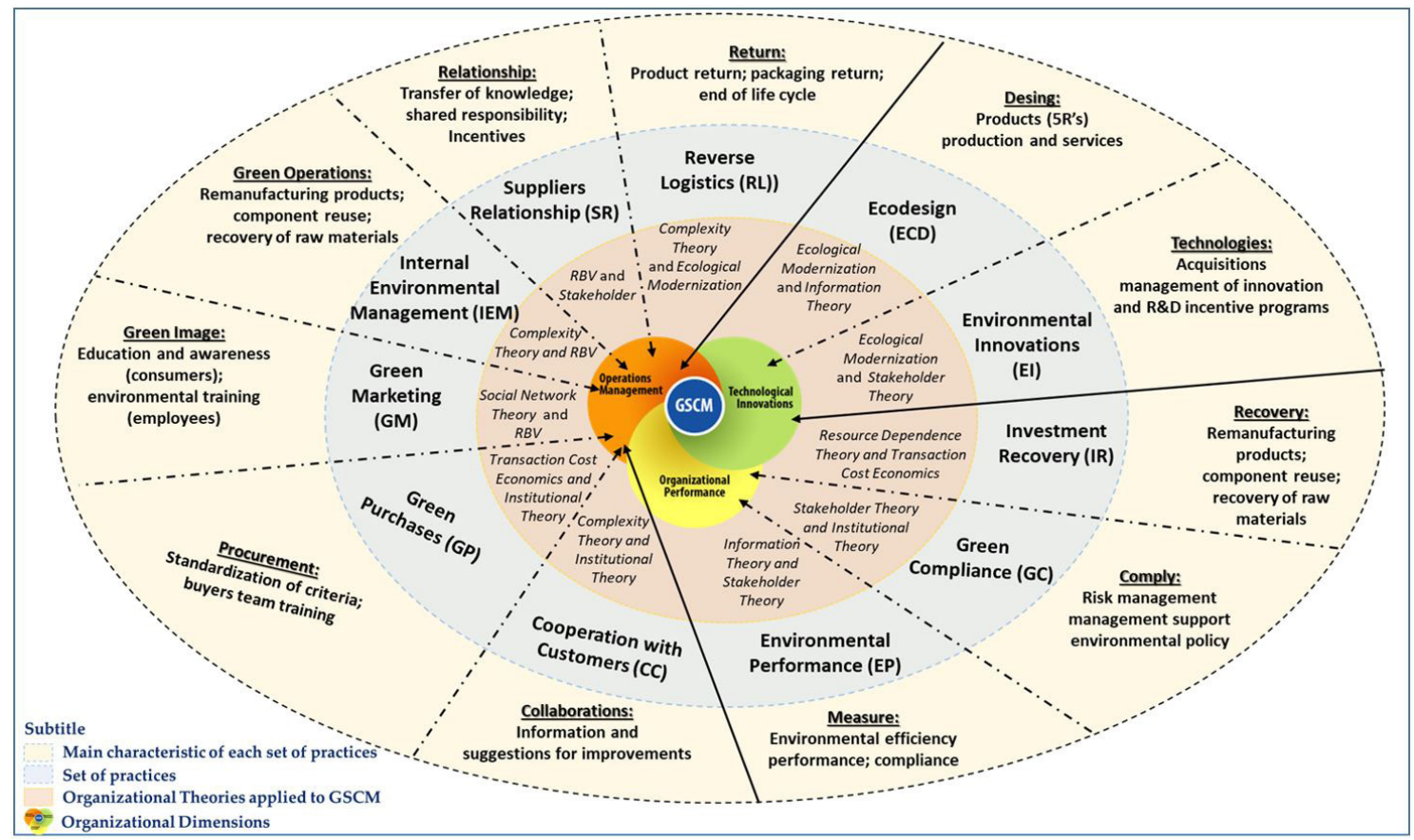

Figure 1. The practice-context-theory conceptual model. 
A suitable lens to explain IEM practices is the complexity theory, since it seeks to elucidate how difficulties in implementing such practices can be exacerbated by organizational complexities associated with size and relationships with employees, suppliers and customers.

For example, Choi \& Krause (2006) considered that the great intricacy observed in the list of available providers is a key subject on managerial issues, since dimensions such as quantity, degree of differentiation and level of interrelationships between them increase the complexity of portfolio management. Merging the complexity theory with RBV's principles in order to identify the creation of capabilities, increasing supplier reliance and improving the quality indicators of this relationship, is an interesting research topic (Vachon \& Klassen, 2008). Stakeholders theory, in particular stakeholder-agency theory can be used to explain how powerful internal stakeholders such a middle and top management become committed and involved in the implementation and enforcement of environmental practices.

\subsection{Green Purchasing (GP)}

GP refers to a set of procurement policies that encompass environmental concerns related to raw materials (extraction and acquisition), supplier selection, distribution, packaging, recycling, reuse, resource reduction, management systems and final destination of products. Although some authors such as Zhu et al. (2015) and Thun \& Muller (2010) include in this construct the practices in supplier relationship managements, such as development and selection, our analysis observed a maturity of this relationship, justifying its treatment as a separate construct.

In order to develop a GSCM, it is necessary to implement procurement strategies for environmentally sustainable products. Liang \& Reiner (2013) confirm that environmentally sustainable procurement results in a reduction of waste and hazardous materials. In addition, GP practices play a significant role in helping organizations reduce pollution and waste through strategies such as recycling, demolition or sorting and use of biodegradable packaging. GP practices take place within framework of chain components, in the context of operations management. There are ample opportunities to investigate the various perspectives of transaction cost economics in GP studies, such as assessing the actual costs of decision-making processes related to those practices (Zsidisin \& Siferd, 2001).

On the other hand, isomorphic pressures may lead companies to institutionalize GP practices in terms of coercive, normative or mimetic pressure, thereby opening up new research opportunities associated with the institutional theory.

\subsection{Cooperation with Customers (CC)}

CC takes place to promote reflection on products and processes through customer participation, which provides collaborative perceptions and suggestions (Sarkis et al., 2011). The present study considered that CC takes place within the scope of chain components, in the context of operation management.

Complexity theory is a good (sorely underused) analysis tool, since it suggests that complexity in the organizational context can be defined by the heterogeneity or diversity of environmental factors, such as customers, suppliers, government rules, and technological advances (Zhu \& Liu, 2010). Thus, external activities such as project delivery and multiple specifications for cooperation with customers and product returns are clear examples of how that diversity can be assessed through the perspective of complexity (Zhu \& Liu, 2010). By including the institutional theory as a complementary lens, an extended view of the problem is outlined from the perspective of external pressures in order to influence companies to adopt CC practices.

\subsection{Ecodesign (ECD)}

ECD can be characterized as a method to create projects that encompass environmental variables as basic parameters in product development. It aims to develop an understanding of how design decisions affect a product in relation to its environmental compatibility and such practices are basically focused on green design and product lifecycle (Srivastava, 2007).

ECD takes place within the scope of business processes, in the context of technological innovations, and aims to design and redesign products, services and processes. The Ecological Modernization theory is a very adequate lens to explain this practice. For example, the dimension of technological innovation suggests that organizations can overcome obstacles that hinder innovation and, thus, attain operational opportunities to improve environmental 
performance. An alternative conception regarding the set of ECD practices is provided by the Information Theory, which highlights the existence of two perspectives of interaction between organizations, clients and suppliers. One perspective points to the sharing of environmental information to remedy the asymmetry of information on organizational practices, such as the development of new products. Another perspective relies on the possibility of cooperation through the sharing of information about environmental technologies for the co-development of recyclable products and cleaner processes. Both perspectives are congruent with the set of ECD practices.

\subsection{Investment Recovery (IR)}

The investment recovery (IR) aims to rethink the life cycle of a product through practices that lead to recovery and product disposal, and sale of surplus or obsolete equipment. There are three different recovery policies: product remanufacturing, reuse of components and raw material recovery (Zhu et al., 2016), representing important elements in pollution mitigation and contributing to environmental and economic performance. In a study Zhu et al. (2016) considered the investment recovery as a guide for the implementation of GSCM practices and, therefore, it is intertwined with SC's environmental management practices, government policies and reverse logistics systems (Zhu et al., 2008a, 2016). This construct, according to the reliance on the interrelationship by chain members, encompasses the organizational context and performance within the organizational structure. A suitable lens to explain IR practices is the Resource Dependence Theory (RDT), because it assumes that companies rely on resources provided by other people and organizations in order to sustain growth.

In GSCM, IR practices rely on organizational resources that require strengthening of the chain partnerships to leverage performance benefits (Carter \& Rogers, 2008). Thus, RDT can be an adequate lens to understand interorganizational behaviors during the GSCM implementation and, more specifically, how these relationships enhance IR practices. The application of RDT together with the transaction cost theory opens up a wide and fertile field to evaluate how these relationships approach the issue of operation resources dependence between suppliers and buyers and the actual costs involved in decision-making processes related to the execution of these practices in different types of transactions (Kelle \& Silver, 1989).

\subsection{Environmental Innovation (El)}

Transforming ideas into innovations with the goal of reducing or eliminating the impacts of the operation requires environmental technologies on greening strategies. Tseng \& Chiu (2013) have shown that innovation management also occurs through interaction with operational and production processes to ensure eco-efficiency. In addition, they found that companies not only introduce environmental practices in operation and production process management, but they also use them to leverage practices geared towards reducing toxic emissions, cooperation with customers and suppliers, among others. Therefore, El practices take place within the scope of business processes, in the context of technological innovations, aiming at leveraging innovative environmental strategies.

Ecological Modernization Theory is a very adequate lens to explain El practices. There is scientific evidence suggesting that EMT can explain that environmental innovations lead companies to build new competencies, both in the operational context and the SC relationships (Søndergård et al., 2004).

Another appropriate lens to explain El is Stakeholder Theory, as stakeholder pressures can lead companies to incorporate new environmental technologies and thereby foster El practices. These pressures may lead companies to invest in green purchasing, SC life cycle and reverse logistics assessment, among others (Sarkis et al., 2010).

\subsection{Environmental Performance (EP)}

Measuring environmental impacts means monitoring operational actions to create indicators that can establish continuous improvement factors for environmental and economic performance. As a result, besides eco-efficiency, the company improves its reputation in the eyes of the customers. For example, Carter et al. (2000) analyzed the relationship between GSCM practices and performances, and the authors noticed that such initiatives are positively associated with environmental and economic performances of the companies.

EP takes place within the framework of the organizational performance. The information theory suggests mechanisms so that companies can transfer information to third parties with the objective of resolving the resulting asymmetries. ISO 14001 certification is a clear example of a signaling instrument (International Organization for Standardization). The information theory is also congruent with stakeholder theory, since it 
sends signals to various stakeholders and institutions, reinforcing the legitimacy of the organization. There are, within the scope of GSCM, significant opportunities to assess satisficing, applications of the signaling theory and dynamics derived from pressures of SC components for GSCM practices (Sarkis et al., 2011).

\subsection{Green Compliance (GC)}

GC can be characterized by the state of being in accordance with a set of environmentally oriented guidelines, specifications and legal requirements (Wan Mahmood, 2013). It is a set of processes used by companies to enforce the legal norms, policies and guidelines established for business and routine activities, with the purpose of avoiding, detecting and treating any deviation or nonconformity that may occur. To this end, it must ensure that employees know, understand and comply with the standards and that their leaders actively support them in operational and business practices in an ethical manner

For example, Hu \& Hsu (2010) referred to compliance when dealing with practical arrangement to comply with legal environmental requirements. Zhu et al. (2008a) referred to compliance practices when dealing with environmental audit systems and compliance with legal requirements. GC takes place within the framework of organizational performance. The stakeholder theory is an adequate lens to explain this practice. There are some research opportunities regarding the role of the stakeholder theory to explain the pressures to adopt GC practices, such as the implementation of environmental audits and certification programs, due to the need for compliance (Vachon, 2007). On the other hand, from the point of view of the institutional theory, there is a vast field of study geared towards explaining how coercive pressures on the part of governments drive corporations to voluntarily adopt GC practices (Clemens \& Douglas, 2006). This studies suggest that coercive pressures are crucial to perform environmental management (Kilbourne et al., 2002). Seen in these terms, an interesting field of analysis lies in finding how normative and coercive pressures, materialized through the GSCM's logic and rules, can become institutional, similar to what happened with life cycle analysis, and how such pressures are internalized by high and medium-commitment management.

\subsection{Green Marketing (GM)}

GM practices can be associated with two lines of action. Planning and execution of the marketing mix to facilitate consumption, production, distribution and promotion to meet the needs of customers regarding environmental issues. The second is related to endomarketing actions as a means to ensure the participation of employees in the production of environmental innovations, training and development geared towards environmental issues (Ellram et al., 2008). GM practices take place within the scope of SC components, in the context of operations management. An appropriate lens to study such practices is the social network theory (SNT), as it helps to understand the general evolution of sustainability and its interconnections (Connelly et al., 2011). Another potential research field associated with GM practices is the construction of a network to share environmental information for organizational practices, such as new product development, environmental cooperation for the development of recyclable products, among other processes (Connelly et al., 2011).

In relation to the development of competitive advantages, from RBV perspective, GM practices may be associated to the creation of collaborative networks that are capable of materializing RBV dimensions in GSCM are opportunities for studies (Lai et al., 2011). As values associated with SC greening are higher downstream (customers) through the creation of capacity and resources that are perceived by the clients, GM practices accord well with the RBV's perspective (Shang et al., 2010).

\subsection{Suppliers Relationship (SR)}

The researched articles strongly emphasized the subject of supplier relationship, with the aim of collaborating, encouraging, cooperating and sharing techniques and knowledge to carry out environmentally friendly practices (Bai \& Sarkis, 2010). In this regard, some activities were highlighted, such as fund allocation to aid in implementing the environmental program, environmental collaboration (design and specifications), which includes environmental requirements for purchasing new items, as well as management of reverse flows of materials and packaging. This construct, due to the reliance on the relationship with the suppliers, is inherent to the organizational context of the operations management within the SC behavior framework.

An appropriate lens to explain supplier relationship (SR) practices relies on the stakeholder theory, since it argues that not all GSCM practices are conducive to the creation of competitive advantages for firms, but they are necessary due to stakeholder pressures (Vachon, 2007). In this case, research opportunities may be 
useful to explain how new technologies and innovations can be shared through collaboration with suppliers, e.g. for new clean technologies. If one broadens the concept of RBV to evaluate the development of resources and capabilities, such as green project partnerships with suppliers associated with increased eco-efficiency or a better delivery performance, an important research field can be properly explored (Vachon \& Klassen, 2006).

\subsection{Reverse Logistics (RL)}

The first study on the subject was published in the late 1980's and was considered as a seminal publication. In that paper, Kelle \& Silver (1989) dealt specifically with reverse logistics by inserting environmental logic into a model that only took into account the economic impacts. Beamon (1998) associated current GSCM concepts with elements of performance measurement, suggesting that the traditional supply chain structure should be broadened to include mechanisms of reverse logistics. Thus, reverse logistics (RL) was addressed by Srivastava (Srivastava, 2007; Sarkis et al., 2011; Zhu et al., 2011, 2015), among others.

The field can be divided into three main areas: distribution planning, stock control, and production planning, with special focus on the differences and similarities with classical logistics methods. The essential RL activities can be divided into actions related to the product and the packaging. In relation to the product, activities of return of raw material to suppliers, as well as retailing, recovering, renewing, remanufacturing and recycling activities, can be identified. Regarding packaging, activities such as reusing, renewing, recovering and recycling can also be observed. This construct, due to the trust in the relationship with SC members, is appropriate for the organizational context of operations management (SC structure). The difficulties in implementing RL practices can be constrained due to broad complexities, which are associated with size and relationships among chain members (Vachon \& Klassen, 2006). The implication is that some activities, such as cooperation with suppliers and customers to return products, involve a dynamic network of relationships in the system.

One opportunity is precisely to incorporate outsourcing into recyclers to harness the prevalence of Internet technology and develop a two-channel reverse chain by introducing online recycling channels (Zhu \& Liu, 2010).

By blending the EMT perspective with the vision of technological innovation, research opportunities are broadened and become useful in explaining how organizations can overcome barriers to innovation and thereby gain operational opportunities to improve performance through RL. The conclusion is that an effective mechanism to encourage green cooperation throughout SC still needs to be developed (Murphy \& Gouldson, 2000).

\section{The model}

The 435 practices identified in the literature gave rise to eleven sets of practices that are representative in terms of their similarity. Based on the revised theories and the main characteristics of these eleven categories, this study proposes a conceptual model that relates the sets of practices with three organizational dimensions, indicating the main theories reviewed that explained these practices.

Figure 1 shows that the implementation of environmental practices happens through the change in operations management, the creation of new organizational performance indicators and the capacity to produce technological innovations. To respond to these pressures or anticipate opportunities, companies change their strategies to achieve eco-efficiency and competitive advantage through SC's business processes, management variables represented by SC components, and the expansion of the membership network the SC structure. The maturity of such practices results in an integrated GSCM.

The dimension of technological innovation (Carter \& Rogers, 2008) presupposes that organizational problems related to the environment occur in the context of business processes, and can be solved through the use of new technologies (Murphy \& Gouldson, 2000).

In this case, ecodesign (ECD) and environmental innovation (EI) practices will enable companies to make changes in their products, services and processes, and this will occur through design change (Vachon \& Klassen, 2006; Zhu \& Liu, 2010) and the acquisition of new technologies (Touboulic \& Walker, 2015; Rao \& Holt, 2005). These practices can be explained by using theoretical lenses such as ecological modernization (EMT), information, stakeholders and resource-based view. To this end, one can use constructs, like environmental innovations and technologies (Sarkis et al., 2011); information asymmetry and dependence (Delmas \& Montiel, 2009; Sarkis et al., 2010); external pressure (Maignan et al., 2002; Miguel \& Campos, 2013) and finally, organizational resources and capacities.

The organizational environmental performance dimension, which occurs within the SC structure, suggests that organizations seek to adopt control and monitoring practices to consolidate a GSCM system through a cooperative network among individuals, aiming to disseminate knowledge and experiences. 
To achieve this goal, it has adopted practices, such as environmental performance (EP), green compliance (GC) and investment recovery (IR) with its own measures, compliance requirements Freeman \& McVea (2001) and recovery strategies (Sarkis et al., 2011).

The theories that can explain such practices are: Institutional, Information, stakeholders, Resource Dependence and Transaction Cost Economics. In this case, constructs such as external pressure (Clemens \& Douglas, 2006; Zhu et al., 2008a; Sarkis et al., 2010; Kilbourne et al., 2002; Miguel \& Campos, 2013) information asymmetry and dependence and cooperation (Delmas \& Montiel, 2009; Sarkis et al., 2010); externalities (Maignan et al., 2002); dependence and cooperation (Carter \& Rogers, 2008) and analysis of costs involved in decision-making processes (Sarkis et al., 2011) may help understand those practices.

The operations management dimension supports practices of reverse logistics (RL), suppliers relationship (SR), internal environmental management (IEM), green marketing (GM), green purchasing (GP) and cooperation with customers (CC), but depends on the level of relations leveraged by SC components to materialize those GSCM practices.

Characteristics like return (Sarkis et al., 2010), relationship (Zsidisin \& Siferd, 2001), operations management (Delmas \& Montiel, 2009), improvement of green reputation (Sarkis et al., 2011; Delmas \& Montiel, 2009) and cooperation direct the efforts to consolidate those practices.

The theories that can be used to explain such practices are the following: Stakeholders, Resource-Based View, Complexity, Ecological Modernization, Institutional, and Transaction Cost Economics. To this end, it is possible to use constructs such as pressures due to externalities (Maignan et al., 2002); organizational resources and capacities; chain interdependence (Vachon \& Klassen, 2006), innovation and environmental technologies, external pressure (Clemens \& Douglas, 2006; Carter \& Rogers, 2008; Sarkis et al., 2010; Miguel \& Campos, 2013) and analysis of the costs involved in decision-making processes.

The dimensions theory model in which practices take place suggests that studies on GSCM should focus on environmental practices, with the objective of integrating all organizational contexts and, thus, covering the entire supply chain. Likewise, studies published to this date point to a need to carry out researches on the integration of theories, aiming at developing new environmental technologies and maximizing innovation in the supply chain.

Accordingly, at least two directions are offered for GSCM research: i) first, new public policies capable of influencing the organization's market logic and customer behavior in terms of compliance requirements and environmental awareness; ii) second, the inexorable path of technological innovations that will provide solutions to the challenges imposed by public policies, market and customers. GSCM practices are consistent with the concept of environmental innovation from the point of view of the presented theories, since innovation usually takes place at the upper echelon of a supply chain and voluntarily or coercively spreads throughout its structure. In this case, there are opportunities for further researches on the mechanisms of innovation diffusion, as well as on the relationships between large and small suppliers and customers for GSCM practices.

\section{Conclusions}

The article integrates practices of GSCM with organizational theories underpinning three contextual perspectives in order to propose a framework, which is able to guide future research. So, our first contribution is a typology of 11 categories of GSCM practices.

Each category comprises several isolated activities that were previously addressed as GSCM practices. Results from this study may hopefully contribute to the maturing of the concept of GSCM practices.

The second contribution is the identification of three organizational dimensions in which such practices occur: technological innovation, organizational performance and operations management.

The third contribution is the alignment of each category of practices and organizational dimension with the selected theoretical lenses that can help future investigations to deepen the analysis of GSCM practices, from the perspective of the theories described here and the integration of different organizational dimensions. These contributions are integrated into a conceptual model of the model of theory of dimensions in which the practices of GSCM take place.

The theoretical mapping and linkage to categories of practices provided by the model will complement existing GSCM typologies which are either practically aimed and therefore do not integrate theory (e.g. Centobelli et al., 2017), or implementation models that rely on one or two theory (e.g. Sauer \& Seuring, 2018) typically institutional theory and/or RBV and Stakeholders theory. We hope our model will facilitate adoption of more variety of theoretical approaches in GSCM research. This will bring new research questions and interpretative lenses. 
Our detailed typology of organizational practices and dimensions, in turn, can add granularity to the propositions of frameworks that have lesser degrees of differentiation between practices (e.g. upstream, organization and downstream practices in Govindan et al., 2014; dyadic and multitier in Sauer \& Seuring, 2018).

The typology of organizational practices and dimensions help to establish a relevant standard and categorization of GSCM practices, so they can be differentiated from routine activities and those that do little to the integration of an environmentally sustainable supply chain.

Future studies may focus on implementing a conceptual model of GSCM practices, identifying the main activities for each set and explaining how the emergence of environmental innovation in organizations or companies puts pressure on them to induce joint companies-suppliers environmental practices.

Limitations are related to the fact that we do not provide empirical applications for questions put forward. Moreover; although great care has been taken to use all references and seek as many practices as possible, some may have been left out.

\section{Acknowledgements}

The authors would like to thank CNPq (The National Council for Scientific and Technological Development) for the financial support of this research.

\section{References}

Akerlof, G. A. (1970). The market for "lemons": quality uncertainty and the market mechanism. The Quarterly Journal of Economics, 84(3), 488-500. http://dx.doi.org/10.2307/1879431.

Arimura, T. H., Darnall, N., \& Katayama, H. (2011). ls ISO 14001 a gateway to more advanced voluntary action? The case of green supply chain management. Journal of Environmental Economics and Management, 61(2), 170-182. http://dx.doi.org/10.1016/j. jeem.2010.11.003.

Bai, C., \& Sarkis, J. (2010). Integrating sustainability into supplier selection with grey system and rough set methodologies. International Journal of Production Economics, 124(1), 252-264. http://dx.doi.org/10.1016/j.jpe.2009.11.023.

Beamon, B. M. (1998). Supply chain design and analysis: models and methods. International Journal of Production Economics, 55(3), 281-294. http://dx.doi.org/10.1016/S0925-5273(98)00079-6.

Campos, L. M. S., \& Vazquez-Brust, D. A. (2016). Lean and Green Synergies in Supply Chain Management. Supply Chain Management, 21(5), 627-641. http://dx.doi.org/10.1108/SCM-03-2016-0101.

Carter, C. R., \& Rogers, D. S. (2008). A framework of sustainable supply chain management: moving toward new theory. International Journal of Physical Distribution \& Logistics Management, 38(5), 360-387. http://dx.doi.org/10.1108/09600030810882816.

Carter, C. R., Kale, R., \& Grimm, C. M. (2000). Environmental purchase and firm performance: an empirical investigation. Transportation Research Part E, Logistics and Transportation Review, 36(3), 219-228. http://dx.doi.org/10.1016/S1366-5545(99)00034-4.

Centobelli, P., Cerchione, R., \& Esposito, E. (2017). Developing the WH2 framework for environmental sustainability in logistics service providers: a taxonomy of green initiatives. Journal of Cleaner Production, 165, 1063-1077. http://dx.doi.org/10.1016/j. jclepro.2017.07.150.

Cherrafi, A., Garza-Reyes, J. A., Kumar, V., Mishra, N., Ghobadian, A., \& Elfezazi, S. (2018). Lean, green practices and process innovation: a model for green supply chain performance. International Journal of Production Economics, 206, 79-92. http://dx.doi.org/10.1016/j. ijpe.2018.09.031.

Chien, M., \& Shih, L. (2007). An empirical study of the implementation of green supply chain management practices in the electrical and electronic industry and their relation to organizational performances. International Journal Environmental, 4(3), 383-394.

Choi, T. Y., \& Krause, D. R. (2006). The supply base and its complexity: implications for transaction costs, risks, responsiveness, and innovation. Journal of Operations Management, 24(5), 637-652. http://dx.doi.org/10.1016/j.jom.2005.07.002.

Clemens, B., \& Douglas, T. J. (2006). Does coercion drive firms to adopt 'voluntary' green initiatives? Relationships among coercion, superior firm resources, and voluntary green initiatives. Journal of Business Research, 59(4), 483-491. http://dx.doi.org/10.1016/j. jbusres.2005.09.016.

Connelly, B., Ketchen, D., \& Slater, S. (2011). Toward a theoretical toolbox for sustainability research in marketing. Journal of the Academy of Marketing Science, 39(1), 86-100. http://dx.doi.org/10.1007/s11747-010-0199-0.

Darnall, N., Jolley, G., \& Handfield, R. (2008). Environmental management systems and Green Supply Chain Management: complements for sustainability? Business Strategy and the Environment, 171), 30-45. http://dx.doi.org/10.1002/bse.557.

Delmas, M., \& Montiel, 1. (2009). Greening the supply chain: when is customer pressure effective? Journal of Economics \& Management Strategy, 18(1), 171-201. http://dx.doi.org/10.1111/j.1530-9134.2009.00211.x.

DiMaggio, P. J., \& Powell, W. W. (1983). The iron cage revisited: Institutional isomorphism and collective rationality in organizational fields. American Sociological Review, 48(2), 147-160. http://dx.doi.org/10.2307/2095101.

Ellram, L. M., Tate, W., \& Carter, C. R. (2008). Applying 3DCE to environmentally responsible manufacturing practices. Journal of Cleaner Production, 16(15), 1620-1631. http://dx.doi.org/10.1016/j.jclepro.2008.04.017.

Eltayeb, T. K., Zailani, S., \& Ramayah, T. (2011). Green supply chain initiatives among certified companies in Malaysia and environmental sustainability: investigating the outcomes. Resources, Conservation and Recycling, 55(5), 495-506. http://dx.doi.org/10.1016/j. resconrec.2010.09.003. 
Freeman, R. E., \& McVea, J. (2001). A stakeholder approach to strategic management (Working Paper, No. 01-02). Charlottesville: Darden Business School. http://dx.doi.org/10.2139/ssrn.263511.

Frooman, J. (1999). Stakeholder influence strategies. Academy of Management Review, 24(2), 191-205. http://dx.doi.org/10.5465/ amr.1999.1893928.

Govindan, K., Sarkis, J., Jabbour, C. J. C., Zhu, Q., \& Geng, Y. (2014). Eco-efficiency based green supply chain management: current status and opportunities. European Journal of Operational Research, 233(2), 293-298. http://dx.doi.org/10.1016/j.ejor.2013.10.058.

Hart, S. L. (1997). Beyond greening: strategies for a sustainable world. Harvard Business Review, 75(1), 66-76.

Hartmann, J., \& Moeller, S. (2014). Chain liability in multitier supply chains? Responsibility attributions for unsustainable supplier behavior. Journal of Operations Management, 32(5), 281-294. http://dx.doi.org/10.1016/j.jom.2014.01.005.

Holt, D., \& Ghobadian, A. (2009). An empirical study of green supply chain management practices amongst UK manufacturers. Journal of Manufacturing Technology Management, 20(7), 933-956. http://dx.doi.org/10.1108/17410380910984212.

Hu, A. H., \& Hsu, C. (2010). Critical factors for implementing green supply chain management practice: an empirical study of electrical and electronics industries in Taiwan. Management Research Review, 33(6), 586-608. http://dx.doi.org/10.1108/01409171011050208.

Islam, S., Karia, N., Fauzi, F. B. A., \& Soliman, M. (2017). A review on green supply chain aspects and practices. Management \& Marketing., 12(1), 12-36. http://dx.doi.org/10.1515/mmcks-2017-0002.

Jänicke, M. (2008). Ecological modernisation: new perspectives. Journal of Cleaner Production, 16(5), 557-565. http://dx.doi.org/10.1016/j. jclepro.2007.02.011.

Kelle, P., \& Silver, E. A. (1989). Forecasting the returns of reusable containers. Journal of Operations Management, 8(1), 17-35. http:// dx.doi.org/10.1016/S0272-6963(89)80003-8.

Kilbourne, W. E., Beckmann, S. C., \& Thelen, E. (2002). The role of the dominant social paradigm in environmental attitudes: a multinational examination. Journal of Business Research, 55(3), 193-204. http://dx.doi.org/10.1016/S0148-2963(00)00141-7.

Koberg, E., \& Longoni, A. (2019). A systematic review of sustainable supply chain management in global supply chains. Journal of Cleaner Production, 207, 1084-1098. http://dx.doi.org/10.1016/j.jclepro.2018.10.033.

Lai, K.-H., Lun, V. Y. H., Wong, C. W. Y., \& Cheng, T. C. E. (2011). Green shipping practices in the shipping industry: conceptualization, adoption, and implications. Resources, Conservation and Recycling, 55(6), 631-638. http://dx.doi.org/10.1016/j.resconrec.2010.12.004.

Liang, X., \& Reiner, D. M. (2013). The evolution of stakeholder perceptions of deploying CCS technologies in China: survey results from three stakeholder consultations in 2006, 2009 and 2012. Energy Procedia, 37, 7361-7368. http://dx.doi.org/10.1016/j.egypro.2013.06.677.

Maditati, D. R., Munim, Z. H., Schramm, H.-S., \& Kummer, S. (2018). A review of green supply chain management: from bibliometric analysis to a conceptual framework and future research directions. Resources, Conservation and Recycling, 139, 150-162. http:// dx.doi.org/10.1016/j.resconrec.2018.08.004.

Maignan, 1., Hillebrand, B., \& McAlister, D. (2002). Managing socially-responsible buying: how to integrate non-economic criteria into the purchasing process. European Management Journal, 20(6), 641-648. http://dx.doi.org/10.1016/S0263-2373(02)00115-9.

Malviya, R. K., \& Kant, R. (2015). Green Supply Chain Management (GSCM): a structured literature review and research implications. Benchmarking, 22(7), 1360-1394. http://dx.doi.org/10.1108/BlJ-01-2014-0001.

Merry, U. (1995). Coping with uncertainty: insights from the new sciences of chaos, self-organization, and complexity. Westport: Praeger.

Miguel, P. A. C., \& Campos, L. M. S. (2013). Practices of environmental and social responsibility in companies that adopt the Brazilian award for performance excellence. International Journal of Business Excellence, 6(4), 488-503. http://dx.doi.org/10.1504/IJBEX.2013.054723.

Mitchell, R. K., Agle, B. R., \& Wood, D. J. (1997). Toward a Theory of Stakeholder ldentification and Salience: defining the principle of who and what really counts. Academy of Management Review, 22(4), 853-886. http://dx.doi.org/10.5465/amr.1997.9711022105.

Mol, A. P. J., \& Spaargaren, G. (1993). Environment, modernity and the risk-society: the apocalyptic horizon of environmental reform. International Sociology, 8(4), 431-459. http://dx.doi.org/10.1177/026858093008004003.

Murphy, J., \& Gouldson, A. (2000). Environmental policy and industrial innovation: integrating environment and economy through ecological modernisation. Geoforum, 31(1), 33-44. http://dx.doi.org/10.1016/S0016-7185(99)00042-1.

Oliveira, U. R., Espindola, L. S., Silva, I. R., \& Silva, I. N. (2018). A systematic literature review on green supply chain management: research implications and future perspectives. Journal of Cleaner Production, 187, 537-561. http://dx.doi.org/10.1016/j.jclepro.2018.03.083.

Pfeffer, J., \& Salancik, G. R. (1978). The external control of organizations: a resource dependence perspective. New York: Harper \& Row.

Rao, P., \& Holt, D. (2005). Do green supply chains lead to competitiveness and economic performance? International Journal of Operations \& Production Management, 25(9), 898-916. http://dx.doi.org/10.1108/01443570510613956.

Rauer, J., \& Kaufmann, L. (2015). Mitigating external barriers to implementing green supply chain management: a grounded theory investigation of green-tech companies rare earth metals supply chains. The Journal of Supply Chain Management, 51(2), 65-88. http://dx.doi.org/10.1111/jscm.12063.

Rostamzadeh, R., Govindan, K., Esmaeili, A., \& Sabaghi, M. (2015). Application of fuzzy VIKOR for evaluation of green supply chain management practices. Ecological Indicators, 49(0), 188-203. http://dx.doi.org/10.1016/j.ecolind.2014.09.045.

Sang, M. L., Jin Sung, R., Donghyun, C., \& Yonghwi, N. (2013). Pressures affecting green supply chain performance. Management Decision, 51(8), 1753-1768. http://dx.doi.org/10.1108/MD-12-2012-0841.

Sarkis, J. (2009). A boundaries and flows perspective of green supply chain management. Massachusetts: George Perkins Marsh Institute, Clark University.

Sarkis, J., \& Cordeiro, J. J. (2012). Ecological modernization in the electrical utility industry: an application of a bads-goods DEA model of ecological and technical efficiency. European Journal of Operational Research, 219(2), 386-395. http://dx.doi.org/10.1016/j. ejor.2011.09.033.

Sarkis, J., Gonzalez-Torre, P., \& Adenso-Diaz, B. (2010). Stakeholder pressure and the adoption of environmental practices: The mediating effect of training. Journal of Operations Management, 28(2), 163-176. http://dx.doi.org/10.1016/j.jom.2009.10.001.

Sarkis, J., Zhu, Q., \& Lai, K. H. (2011). An organizational theoretic review of green supply chain management literature. International Journal of Production Economics, 130(1), 1-15. http://dx.doi.org/10.1016/j.ijpe.2010.11.010. 
Sauer, P. C., \& Seuring, S. (2018). A three-dimensional framework for multi-tier sustainable supply chain management. Supply Chain Management, 23(6), 560-572. http://dx.doi.org/10.1108/SCM-06-2018-0233.

Shang, K. C., Lu, C. S., \& Li, S. (2010). A taxonomy of green supply chain management capability among electronics-related manufacturing firms in Taiwan. Journal of Environmental Management, 91(5), 1218-1226. http://dx.doi.org/10.1016/j.jenvman.2010.01.016. PMid:20181423.

Singhal, P. (2013). Green Supply Chain and ecodesign in electronic industry. Delhi Business Review, 14(1), 57-78.

Søndergård, B., Hansen, O. E., \& Holm, J. (2004). Ecological modernisation and institutional transformations in the Danish textile industry. Journal of Cleaner Production, 12(4), 337-352. http://dx.doi.org/10.1016/S0959-6526(03)00049-0.

Sousa Jabbour, A. B. L., Vazquez-Brust, D., Jabbour, C. J. C., \& Latan, H. (2017). Green supply chain practices and environmental performance in Brazil: survey, case studies, and implications for B2B. Industrial Marketing Management, 66, 13-28. http://dx.doi. $\operatorname{org} / 10.1016 /$ j.indmarman.2017.05.003.

Srivastava, S. K. (2007). Green supply-chain management: a state-of-the-art literature review. International Journal of Management Reviews, 9(1), 53-80. http://dx.doi.org/10.1111/j.1468-2370.2007.00202.x.

Thun, J., \& Muller, A. (2010). An empirical analysis of green supply chain management in the German automotive industry. Business Strategy and the Environment, 19, 119-132.

Touboulic, A., \& Walker, H. (2015). Theories in sustainable supply chain management: a structured literature review. International Journal of Physical Distribution \& Logistics Management, 45(1-2), 16-42. http://dx.doi.org/10.1108/1JPDLM-05-2013-0106.

Tseng, M.-L., \& Chiu, A. S. F. (2013). Evaluating firm's green supply chain management in linguistic preferences. Journal of Cleaner Production, 40, 22-31. http://dx.doi.org/10.1016/j.jclepro.2010.08.007.

Tseng, M.-L., Islam, M. S., Karia, N., Fauzi, S. A., \& Afrin, S. (2019). A literature review on green supply chain management: trends and future challenges. Resources, Conservation and Recycling, 141, 145-162. http://dx.doi.org/10.1016/j.resconrec.2018.10.009.

Vachon, S. (2007). Green supply chain practices and the selection of environmental technologies. International Journal of Production Research, 45(18-19), 4357-4379. http://dx.doi.org/10.1080/00207540701440303.

Vachon, S., \& Klassen, R. D. (2006). Extending green practices across the supply chain: the impact of upstream and downstream integration. International Journal of Operations \& Production Management, 26(7), 795-821. http://dx.doi.org/10.1108/01443570610672248.

Vachon, S., \& Klassen, R. D. (2008). Environmental management and manufacturing performance: the role of collaboration in the supply chain. International Journal of Production Economics, 111(2), 299-315. http://dx.doi.org/10.1016/j.ijpe.2006.11.030.

Wan Mahmood, W. H. (2013). Manufacturing performance in green supply chain management. World Applied Sciences Journal, 21(2), 76-84. http://dx.doi.org/10.5829/idosi.wasj.2013.21.1010.

Wasserman, S., \& Faust, K. (1994). Social network analysis: methods and applications. New York: Cambridge University Press. http:// dx.doi.org/10.1017/CB09780511815478.

Weale, A. (1992). The new politics of polluition. Journal of Public Policy, 12, 296-297.

Williamson, 0. E. (1981). The economics of organization: the transaction cost approach. American Journal of Sociology, 87(3), 548-577. http://dx.doi.org/10.1086/227496.

Zhu, Q., \& Liu, Q. (2010). Ecodesign planning in a Chinese telecommunication network company: Benchmarking its parent company. Benchmarking, 17(3), 363-377. http://dx.doi.org/10.1108/14635771011049344.

Zhu, Q., \& Sarkis, J. (2004). Relationships between operational practices and performance among early adopters of green supply chain management practices in Chinese manufacturing enterprises. Journal of Operations Management, 22(3), 265-289. http://dx.doi. org/10.1016/j.jom.2004.01.005.

Zhu, Q., \& Sarkis, J. (2007). The moderating effects of institutional pressures on emergent green supply chain practices and performance. International Journal of Production Research, 45(18-19), 4333-4355. http://dx.doi.org/10.1080/00207540701440345.

Zhu, Q., Geng, Y., Sarkis, J., \& Lai, K.-H. (2011). Evaluating green supply chain management among Chinese manufacturers from the ecological modernization perspective. Transportation Research Part E, Logistics and Transportation Review, 476), 808-821. http:// dx.doi.org/10.1016/j.tre.2010.09.013.

Zhu, Q., Geng, Y., Sarkis, J., \& Lai, K.-H. (2016). Shifting Chinese organizational responses to evolving greening pressures. Ecological Economics, 121, 65-74. http://dx.doi.org/10.1016/j.ecolecon.2015.11.010.

Zhu, Q., Sarkis, J., \& Lai, K. (2008a). Confirmation of a measurement model for green supply chain management practices implementation. International Journal of Production Economics, 111(2), 261-273. http://dx.doi.org/10.1016/j.jpe.2006.11.029.

Zhu, Q., Sarkis, J., Cordeiro, J., \& Lai, K.-H. (2008b). Firm-level correlates of emergent green supply chain management practices in the Chinese context. Omega, 36(4), 577-591. http://dx.doi.org/10.1016/j.omega.2006.11.009.

Zhu, Q., Sarkis, J., \& Lai, K.-H. (2012). Green supply chain management innovation diffusion and its relationship to organizational improvement: an ecological modernization perspective. Journal of Engineering and Technology Management, 29(1), 168-185. http://dx.doi.org/10.1016/j.jengtecman.2011.09.012.

Zhu, Q., Sarkis, J., \& Lai, K.-H. (2015). Reprint of Supply chain-based barriers for truck-engine remanufacturing in China. Logistics and Transportation Review, 74, 94-108. http://dx.doi.org/10.1016/j.tre.2014.12.004.

Zsidisin, G. A., \& Siferd, S. P. (2001). Environmental purchasing: a framework for theory development. European Journal of Purchasing and Supply Management, 7(1), 61-73. http://dx.doi.org/10.1016/S0969-7012(00)00007-1. 